\title{
Translating Proper Names: a Functionalist Approach
}

\author{
Anastasia Parianou \\ Ionian University, Greece
}

\begin{abstract}
Proper names create special problems for translators. A typology of proper names is presented and their use in aesthetic-expressive and informative texts is discussed. Some of the major problems faced by translators are considered with examples from English, German, French, and Greek. Some suggestions for translation considering the communicativefunctional roles of proper names are given.
\end{abstract}

Introduction

Proper names are neglected theoretically and are regarded as a rather heterogeneous group, difficult to handle according to established conventions (Danielsson and Mühlenbock 1998, 266). Similarly, proper names are considered to exist "outside" languages and are thus found in few monolingual dictionaries and in even fewer bilingual ones.

Proper names can be regarded as untranslatable objects and to have, as Mill stated, no inherent meaning or connotation (Newmark 1981, 70) until a description referring to the same object is supplied. It is obvious that this is not a practical or helpful standpoint for the translation of proper names (cf. Danielsson and Mühlenbock 1998, 266). The fact that proper names may be different from common nouns should not be an argument against their translatability, which is determined by the communicative-pragmatic function of a text (Gläser 2005, 264). In fact proper names belong to interdisciplinary research that affects disciplines as diverse as anthropology, history, law, linguistics, philosophy, social psychology, and sociology. As part of an interdisciplinary scientific domain, proper names are involved in translation studies in naming and social structure in various cultures; in literary names; in intercultural aspects of comparison of proper name systems, since intercultural features are relevant to translation studies; in the relations between cultural history

Names 55.4 (December 2007): 407-416

ISSN: 0027-7738

(C) 2007 by The American Name Society 


\section{Names 55.4 (December 2007)}

and the choice of a name (such as the translation of names of historical figures); in legal aspects of naming, especially concerning brand names and trade names; ${ }^{1,2}$ in deonomastics, where common nouns are formed from proper names and their transfer into other languages; and in one of the latest interdisciplinary fields, cognitive studies. The cognitive approach uses proper names to shed light on such phenomena as the fact that proper names constitute a linguistic category likely to provoke retrieval difficulties not only for healthy adults but for some brain-injured patients proper name recall is their only linguistic problem (Valentine, Brennen, and Brédart 1996, xi). All of these approaches call for cooperation between disciplines, and translation studies cannot but profit from such an interdisciplinary approach.

\section{Categories of Proper Names}

From the "conventionalist" theory that proper names are arbitrary (Jespersen, Christophersen, Gardiner), have no meaning and thus differ from common names (John Stuart Mill) and that all proper names are "synonymous" (Togeby), we come to the "naturalist" theory which claims that every name is an "exclusive individual prerogative" (the Stoics, Dionysius Thrax, Apollonius Disculus, Roman grammarians Diomedes, Donatus, and Consentius, the Port Royal grammarians, Sweet) and that proper names are more meaningful than common names (the Stoics, the Roman grammarian Diomedes, Sweet, Jespersen, Bréal) (cf. Superanskaja 1973, 46-88; Salmon Kovarski 2002, 83-84). Today proper names are transformed into meaningful linguistic items by means of logical, semiotic, social, ethnic, historical, affective, cultural, pragmatic and psychological indicators. All these indicators, together with the variety of proper names, manifest themselves when attempting to determine the main categories of proper names, which include:

Personal names and personifications: surnames, given names, nicknames and pseudonyms, names for supernatural or imagined beings, personified animals or names of unique animals or objects such as Mickey Mouse and Bucephalus, and dolls' names such as Barbie;

Geographical names: names of cities, villages, countries, islands, lakes, mountains, rivers, and astronomic objects;

Names of institutions and facilities: public authorities, societies, cinemas, hospitals, hotels, libraries, museums or restaurants, ranks, medals, and titles, habits, festivals and religious periods, languages; 
Names of unique objects and works of art: monuments (Acropolis, Taj Mahal), buildings (Empire State Building), ships (Vasa, Titanic) or other unique objects (Excalibur, the Mona Lisa), technology and science, books and other publications;

Trademark names: brand names and trademarks.

Names of unique events: historical, prehistoric and geological periods (the Second World War, Reichskristallnacht).

There are other possible categorizations, such as that established by Danielsson and Mühlenbock (1998, 267-8) which includes personal names, object names, place names, group names, art names, trademark names, and the names of historical events, while Newmark's categorization (1982, $70 \mathrm{ff}$ ) includes historical figures, literary proper names, categories of objects (trademarks, brand names and proprietary names), geographical names, forms of address, names of firms, private institutions, schools, universities, hospitals, etc., and the names of newspapers, journals and periodicals. No single categorization includes all possible name categories and categories may not be clearly distinct one from another. For example, an institution's name can be identical with that of a building (Whitehall, White House) or a personal name identical with a geographical or an art name (female names Lourdes and Chelsea, male names London, Boston and Equator, all called after geographical names, and the art name Mona Lisa).

\section{Text Type Categories and Text Functions of Proper Names}

To establish further categories of proper names, we must first present the two major text-type categories where proper names are to be found: aesthetic-expressive texts (mostly literary) and informative texts such as textbooks, reports, papers, and articles.

The selection of proper names in literary, i.e. aesthetic-expressive texts, depends wholly on the author and is motivated and meaningful rather than arbitrary and conventional. In this case, "proper names are the result of a non-arbitrary, 'significant' choice and require specific competence on the part of the translator in selecting an equifunctional sign in the target language" (Salmon Kovarski 2002, 85). Unfortunately, literary proper names are very often not translated, but simply taken over from the source language or have an established translation in a particular 


\section{Names 55.4 (December 2007)}

language (Newmark 1981, 71). ${ }^{3}$ The result, due to their non- translation in the target language, is that in languages with different morphological and semantic structures, proper names are considered to be arbitrary, insignificant, meaningless and serving no function. Luca Manini (1996, 161-78) suggests two reasons for the non-translation of proper names: the risk of annihilating the cultural context of the source language and the difficulty of translating allusions, wordplays, and ambiguity. Let us take an example from Thomas Mann's novel The Buddenbrooks, which acts as a social status indicator. ${ }^{4}$ The name of a woman helping young Tony (Antonie) Buddenbrook make up her dowry is Mamsell Bitterlich. She belongs to the class of domestic servants, with no chance of escaping from her bitter existence. The allusion Mann wanted to create with this name goes back to Matthew 26, 75: "And he went outside and wept bitterly" (Tyroff 1975, 111). Even if the connection with the Bible is not made by all readers, it happens that bitterlich 'bitterly' is more understandable in English than in French, Greek, and many other languages. (In these cases the translator might add a note focusing on the meaningfulness of the name.)

In his novel, Effi Briest, Theodor Fontane introduces Dr. Alonzo Gieshübler in an attempt to create a name with evident contrast and conflict (southern influence from Italy for Alonzo and northern influence from Germany for Gieshübler). Thomas Mann created the same cultural and linguistic contrast in the name Tonio Kröger, which symbolizes a combination of the conflicting and identity-imbalanced title character (Debus 2004, 4) and includes the antitheses of north and south, spirit and life, bourgeois and artistic life, and bad health and good health in a geographical-genealogical-sociological structure (Tyroff 1975, 89). On the other hand, in Mann's Magic Mountain, the character of Madame Chauchat (from French chaud 'hot' and chat 'cat') contains an ethnic indicator in the form of a foreign name of intense connotational and emotional-erotic value. It certainly helps French-speaking readers in a non-French text understand the meaning of this name, but it is not very helpful for speakers of other language communities. Other foreign names, such as the Greek names Madame Kapatsoulias from the island of Lesbos or Polypraxios, refer to an erotic atmosphere once again, where both characters of the Magic Mountain have love affairs, Polypraxios (poly 'many', praxis 'act, action'), in particular having more than one. If readers are unable to pronounce or understand the meaning of the non-translated proper name, the prevalent function, in the case where the 
readers are able to pronounce but not understand the proper name, is the "sound effect;" if not, the prevalent effect will be the "visual effect" at the mere sight of the name's morphology, with no clear idea of its pronunciation. Both sound and visual effects give a "foreignizing" image to the proper name, which is the image the author intended to give in the first place. So the author's expectations of the names and the effect of his dictum nomen est omen (or as originally used by Plautus nomen atque omen) on the foreign readers of the text are fulfilled.

The meaningfulness of names becomes even more important when it comes to humorous names that remain untranslated, such as in Pushkin's Eugene Onegin where Petushkov 'little rooster' is described as "the local dandy" and Buyanov 'ruffian' is referred to as "my cousin Buyanov." Similarly, in A Slander, Chekhov's eager junior assessor of taxes is named Mzda 'bribe'. Masha Shamrayeva 'noisemaker', a not-too-devoted woman married to a schoolmaster, and Medvedenko 'little bear', a kind and poor soul, not too clever, provide us with more examples.

Further functions of proper names could be mentioned, but these show that social status and the ethnic, affective, cultural-historical, and political situation in which the name is embedded are important factors in the connotations of proper names.

The Role of Proper Names in Translation

When we mention proper names, personal and place names come to mind as the most typically-mentioned types of proper names, since they belong to the two major categories of names. Where is the difficulty there for translation? Or to put it another way, is it that difficult to translate a few names of persons and places which in any case constitute but a very small part of a text? The prompt answer is that there will surely be some dictionaries to help the translator. Another answer could be that they are not translatable, since these names always remain as in the source language and are only slightly changed to fulfill the language conventions of the target language. But things are not that easy. Proper names include pseudonyms and nicknames, which in most cases are meaningful, semantically loaded and not arbitrary at all. Proper names also include temporal names (names of festivals and religious periods such as Christmas, Ramadan, Easter, and Halloween), and animal names and titles, which all presuppose a cultural and linguistic background and pose potential translation problems. First of all, proper names must be recognized. An unsuccessful translation example of this kind is the name 


\section{Names 55.4 (December 2007)}

of the French singer and actress Margo Lion. The French version la

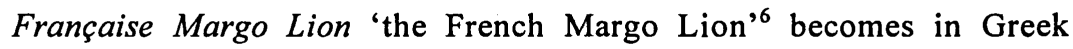

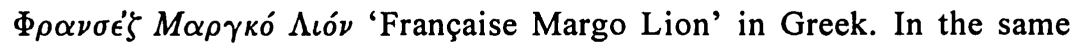
vein, Marshal Antonescu (the military rank of marshal) is not translated into Greek as a rank (marshal $=\sigma \tau \rho \alpha \tau \alpha \dot{\alpha} \chi \eta \varsigma$ ) but as the proper name

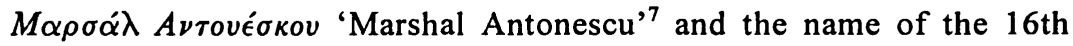
century French composer Claude Lejeune was translated as $K \lambda \alpha u ́ \delta \iota \varsigma^{\circ} \circ$

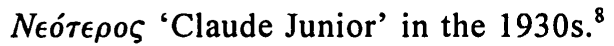

Another interesting group of names regarding translation are brand and trade names, a feature of the commercial world typical of the 20th century with the use of widespread advertising. The general public's opinion about names applied to trade or product names is that they are very easily rendered in the target language without any changes. In translation practice, things turn out to be different. Künzli $(2005,32-44)$ enumerates a list of possible problems as to the translation of the product name GALEO 4710 (a French telephone/answering machine/fax device): the presence or absence of a definite article in the German translation (der Galeo or Galeo); the need to attribute gender to the product name (der Galeo or das Galeo); whether to change or preserve the product name; and rhetorical reinforcement of the product name by the use of possessive modifiers: is it your Galeo, or rather this exciting new appliance allows you to...?

The importance of proper names in informative texts becomes evident in the following figures from the medical domain. Out of the 16,401 words from the French International Classification of Diseases (ICD-10), 1,212 are proper names (Bodenreider and Zweigenbaum 2000,3). Proper names, to use Gile's $(1984,81)$ terms, can include both internal (connected with meaning) and external redundancy (connected with form). Proper names in biomedical texts, for example, show both internal and external redundancy and the frequently used compound proper names can lead to various translation situations. Morphologically similar compound proper names with internal redundancy are Bunsen burner in English, Bunsenbrenner in German, bec Bunsen in French, and $\lambda v \chi \nu i \alpha$ Bunsen in Greek. ${ }^{9}$ Another easily handled situation is the translation of compound proper names such as the universal eponym Achilles in Achilles tendon, which is

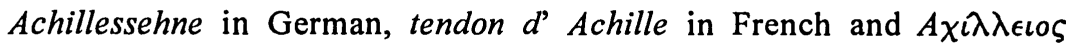
$\tau \epsilon ́ \nu o \nu \tau \alpha \varsigma$ in Greek, or Parkinson's disease, maladie de Parkinson in French, Morbus Parkinson or Parkinson-Krankheit in German, and Nóбos Parkinson in Greek. There are more ambiguous compound proper names 
in medical texts where an onymic constituent is added in one language such as Latin relapsing panniculitis, which is Weber-Christian disease in English, maladie de Weber-Christian in French, but Pfeifer-WeberChristian-Krankheit in German. Another example is pouch of Douglas, which is cul-de-sac de Douglas in French, Douglas-Raum or Douglas'scher Raum (Raum here meaning 'region') in German and $\kappa o ́ \lambda \pi \omega \mu \alpha$ rov Douglas in Greek ( $\kappa o ́ \lambda \pi \omega \mu \alpha$ meaning 'recess') (Bodenreider and Zweigenbaum 2000, 2, 3).

Morphologically different proper names can have different forms:

Synonymous compound proper names or older and younger forms. These include Basedow's disease, and the older term Grave's disease. Sensi and his colleagues at Lepetit Research Laboratories in Milan had the habit of giving new compounds nicknames, later substituting names that would be acceptable to scientific journals. Matamycin, for example, was originally nicknamed Mata Hari. In 1957 they isolated a group of antibiotics from the fungus Streptomyces mediterranei (now called Norcadia mediterranea), which they called rifamycins, from the title of the French gangster film, Rififi (Aronson, 1999, 972).

Proper names in English may be common nouns in other languages. These constitute a very special and interesting case of an onymic constituent which is not maintained in the target language, but is substituted with a common noun. Examples from the automotive engineering domain are the English Allen key and its German equivalent Imbussschlüssel, and Beverly shear and Hebelrollenschere; from the economics domain American option and Terminoffene Anleihe; and Norwegian rat and Wanderratte from zoology (Gläser 2005, 271).

Different proper names in English and other languages. From mathematics is English Argand diagram and German Gaußsche Zahlenebene, and from physics English Avogadro number and German Loschmidt'sche Konstante (Gläser 2005, 271).

More intrinsic information in one language. Dippel's oil in English is Dippels Tieröl ('Dippel's animal oil') in German or Condy's fluid in English and Condy'sche Desinfektionsflüssigkeit ('Condy's disinfection fluid') in German (Gläser 2005, 272).

Circumscription of the English proper name in other languages. English Wegener theory in German becomes Theorie der Kontinentalverschiebung ('theory of continental drift') (Gläser 2005, 272). All these examples can pose considerable challenges to the untrained translator. 


\section{Names 55.4 (December 2007)}

\section{Proper Names and Types of Translations}

What is the guideline for a functional translation of proper names in all textual, cultural and other environments? Neubert's distinction (1968, $21 \mathrm{f}$ in Gläser 2005: 264-5) according to the pragmatic function, leads to four types of proper names translation: texts with the same targets, source and target language readers such as experts, laymen, children); texts dealing with subjects having a specific source-text background such as texts on history, law, administration; literary texts with a social or cultural background of the source-text language, but dealing with problems of human life such as world literature addressed to readers of different linguistic and cultural communities; and texts with special target language audiences such as information on cultural activities, tourist attractions, and academic facilities.

\section{Conclusion}

With the exception of the third type of translation, which focuses on literary texts, the other three are appropriate for all kinds of communicative and pragmatic situations. According to the function of the text (e.g., its addressees, target, and linguistic, cultural, social or other background), proper names can be given functions which vary from the original author to the translator. The translator should also not be afraid to omit a name in the target language so as to better serve the target group and effect of the text. This will be the case in popularized texts which address specific target groups such as children, older people, or laymen). After all, translating names is a very challenging task, one which throws into relief a good number of communicative-functional considerations.

\section{Notes}

My thanks to my colleague, William Mallinson, for editing the text.

1. The well-documented legal debate about the name Adrenalin, a registered trademark of the American pharmaceutical firm Parke, Davis \& Co., broke out in 1906 between (the future Nobel Laureate) Henry Dale and Sir Henry Wellcome (one of the founders of the British pharmaceutical firm Burroughs, Wellcome \& Co.), when the former wished to publish a paper in which the word adrenaline appeared. Wellcome objected to the use of adrenaline and suggested the word epinephrine, which Dale considered to be inappropriate and inaccurate. Finally, Wellcome agreed with Dale, and the claims for scientific reputation won over those of commercial propriety (Tansey 1995, 459, 464, 474). Another example, this time from comics literature, is that of the proper name Schurich (the writer Werner Feldmann's boss in real life) in the comic series, Werner. Due to Schurich's disapproval, the author 
was forced to change Schurich to Röhrich. The name of the "Hôtel Simenon" in Liège was not approved by Georges Simenon's heirs, who accused the hotel owners of using the name for commercial purposes which undermined the rights of the novelist (Anonymous, 1991 in Valentine, Brennen, and Brédart 1996, 7).

2. Künzli (2005: 32$)$ rightly maintains that translation of product names-contrary to widely held views-has a very important role to play: "From a translation theory point of view, it is implicitly supposed, however, that [product names] do not raise translation problems. Indeed, translators are simply expected to render them in the target language without making any changes."

3. Proper names in children's literature or those originally addressed to children, such as Alice in Wonderland, are almost always translated or adapted to the source-text language name convention; John in English becomes Jean in French.

4. It is not by chance that we choose examples from the German writer Thomas Mann. Ingeborg Bachmann, one of the most famous Austrian writers, called him a "name magician" (1978, 247; in Debus 2004, 3), probably an allusion to der Zauberer 'the magician', a name by which Mann's two eldest children, Erika and Klaus, used to call him.

5. Translated by G. R. Ledger, 2001 (www.pushkins-poems.com/Yev504.htm). Babette Deutsch's translation (Penguin 1969) is slightly different: "Here's Petushkov, a rural beau;" "My cousin, sleepy-eyed Buyanov."

6. A distinction must be made between the French Margo Lion (1899-1989) and the American-born Broadway producer Margo Lion (born 1944). This is why the original French text which first appeared in the newspaper Le Figaro (21 July 2006) stresses the nationality of French-born Margo Lion. The Greek translation was published in the Greek newspaper To Vima on 19 August 2007.

7. Source: http://www.sarantakos.com/language/amerol2.htm.

8. I owe this example to my colleague, Irmgard Lerch-Kalavrytinou, from the Music Department of the Ionian University.

9. According to Gile $(1984,81)$, the large amount of internal redundancy (redondance interne) makes compound proper names "nettement moins vulnérables aux baisses de concentration de l'auditeur..." ("far less vulnerable to the concentration loss of the listener").

\section{References}

Aronson, Jeff. 1999. "When I use a word . . . That's show business." British Medical Journal 319: 972

Bodenreider, Olivier, and Pierre Zweigenbaum. 2000. "Identifying Proper Names in Parallel Medical Terminologies." In Hasman, Arie, Bernard Blobel, et. al., eds. Medical Infobahn for Europe. Amsterdam: IOS. Pp. 443-47. 
Bachmann, Ingeborg. 1978. "Der Umgang mit Namen." In Koschel, Christine, et. al, eds., Bachmann, Ingeborg: Werke, vol. 4. München: Anhang. Pp. 238-54.

Danielsson, Pernilla, and Katarina Mühlenbock. 1998. "When Stålhandske Becomes Steelglove." In Farwell, David, Laurie Gerber, and Eduard Hovy, eds., Machine Translation and the Information Soup. Berlin: Springer. Pp. 266-74.

Debus, Friedhelm. 2004. "Funktionen literarischer Namen." Sprachreport 1: 2-9 Institut für deutsche Sprache: Mannheim.

Gile, Daniel. 1984. "Les noms propres en interprétation simultanée." Multilingua 3: 79-85.

Gläser, Rosemarie. 2005. Eigennamen in der Arbeitswelt. Leipzig: Leipziger Universitätsverlag.

Künzli, Alexander. 2005. "Le traitement des noms de produits dans la traduction français-allemand." Journal of Specialised Translation 4:3244.

Manini, Luca. 1996. "Meaningful Literary Names: Their Forms and Functions and their Translation." In Delabastita, Dirk ed., The Translator (2). Manchester: St. Jerome. Pp. 161-78.

Neubert, Albrecht. 1968. "Pragmatische Aspekte der Übersetzung." Grundfragen der Übersetzungswissenschaft. Beihefte zur Zeitschrift Fremdsprachen. Leipzig: Enzyklopädie. Pp. 21-33.

Newmark, Peter. 1981. Approaches to Translation. Oxford: Pergamon.

Salmon Kovarski, Laura. 2002. "Anthroponyms, Acronyms and Allocutives in interpreting from Russian." In Garzone, Giuliana, and Maurizio Viezzi, eds., Interpreting in the 21st Century. Amsterdam: Benjamins. Pp. 83-94.

Superanskaja, Aleksandra V. 1973. Obščaja teorija imeni sobstvennogo. Moskva: Nauka.

Tansey, E. M. 1995. "What's in a Name? Henry Dale and Adrenaline, 1906." Medical History 39: 459-76.

Tyroff, Siegmar. 1975. Namen bei Thomas Mann. Bern: Lang.

Valentine, Tim, Tim Brennen, and Serge Brédart. 1996. The Cognitive Psychology of Proper Names. On the importance of being Ernest. London: Routledge. 